
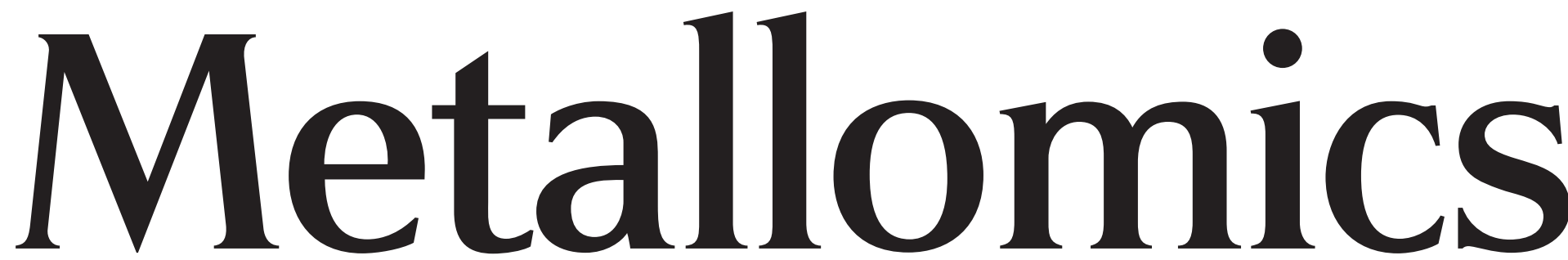

Integrated biometal science

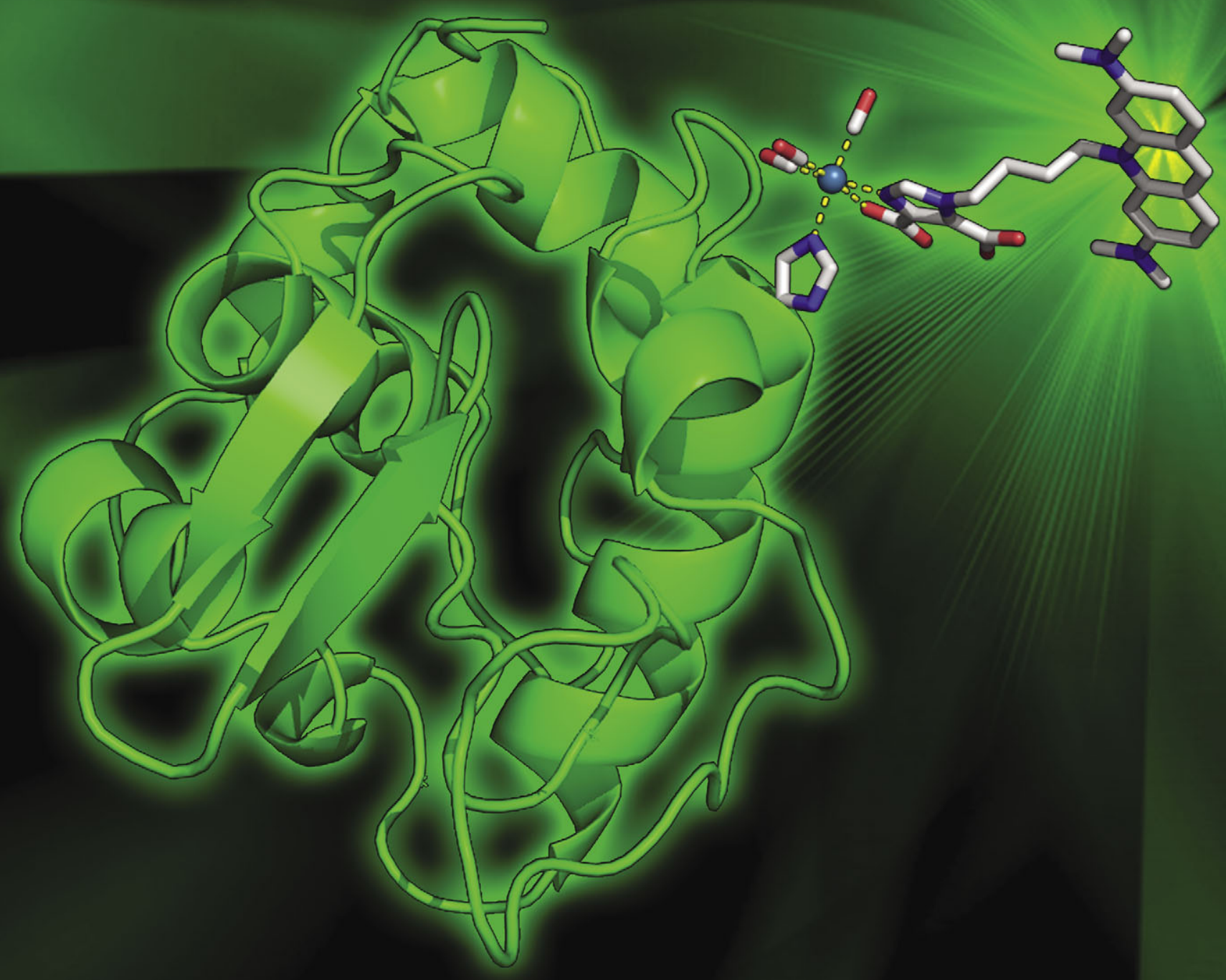

Post-protein binding metal-mediated coupling of an acridine orange-based fluorophore
Indexed in MEDLINE! 


\title{
Post-protein binding metal-mediated coupling of an acridine orange-based fluorophore $\dagger$
}

\author{
Giuseppe Santoro, Olivier Blacque and Fabio Zobi* \\ Received 11th November 2011, Accepted 17th January 2012 \\ DOI: $10.1039 / \mathrm{c} 2 \mathrm{mt} 00175 \mathrm{f}$
}

The HEW lysozyme (Lys) and the $f a c-\left[\operatorname{Re}(\mathrm{CO})_{3}\left(\mathrm{H}_{2} \mathrm{O}\right)_{3}\right]^{+}$complex (1) are used as a simple model system for the description of a new approach to the labelling polypeptides with fluorescent tags. The strategy takes advantage of the reaction of an acridine orange-based fluorophore (AO) with the non-native metal fragment $\mathbf{1}$ hybridized on the enzyme. A synthetic methodology for the quantitative metallation of the protein is first described and it is then shown that the exogenous metal complex can be exploited for the coupling of the fluorescent probe. All Lys-derived species were characterized by various spectroscopic techniques. It is shown that the approach does not significantly alter the activity of the final fluorescent metallo-protein conjugate (Lys2). The accumulation of Lys2 on Micrococcus lysodeikticus bacteria was observed via confocal laser scanning microscopy.

\section{Introduction}

Chemical and genetic methods for specifically labelling proteins with organic fluorophores have significantly impacted our fundamental understanding of proteins dynamics, interactions, localization and reactivity. Due to its high specificity and simplicity, the genetic encoding of fluorescent proteins (FPs, e.g. green fluorescent protein (GFP)) has become in biological research the most popular technique to probe the sophisticated interplay of biomolecules in live cells. ${ }^{1-3}$ FPs, however, have several limitations mainly related to flexibility of their possible modification and to their molecular size (i.e. $27 \mathrm{kDa}$ for GFP) which may potentially interfere with the structure and function of the protein to which they are fused. ${ }^{4-6}$

Chemical techniques remain the most advantageous alternative to fluorescent protein labelling. In particular, affinity labelling based on metal-chelation (Scheme 1A) is largely investigated as it offers high selectivity/affinity, flexibility in the modification of the organic dye and small tag-size. ${ }^{7}$ The methodology is based on the site-specific binding between an amino acid tag fused on the protein of interest and a metal ion complex to which a small fluorescent compound is appended (see Scheme 1). There are mainly four systems for metalchelation affinity labelling: (a) the tetracysteine/biarsenical system, ${ }^{8-13}$ (b) the oligohistidine/nickel-complex system, ${ }^{14-17}$

Institute of Inorganic Chemistry, University of Zürich,

Winterthurerstrasse 190, CH-8057 Zürich, Switzerland.

E-mail:fzobi@aci.uzh.ch; Fax:+41044635 6802;

Tel: +410446354623

$\dagger$ Electronic supplementary information (ESI) available: Tables of $x y z$ coordinates and views of QM/MM optimized structures of Lys1 and Lys2. See DOI: $10.1039 / \mathrm{c} 2 \mathrm{mt} 00175 \mathrm{f}$

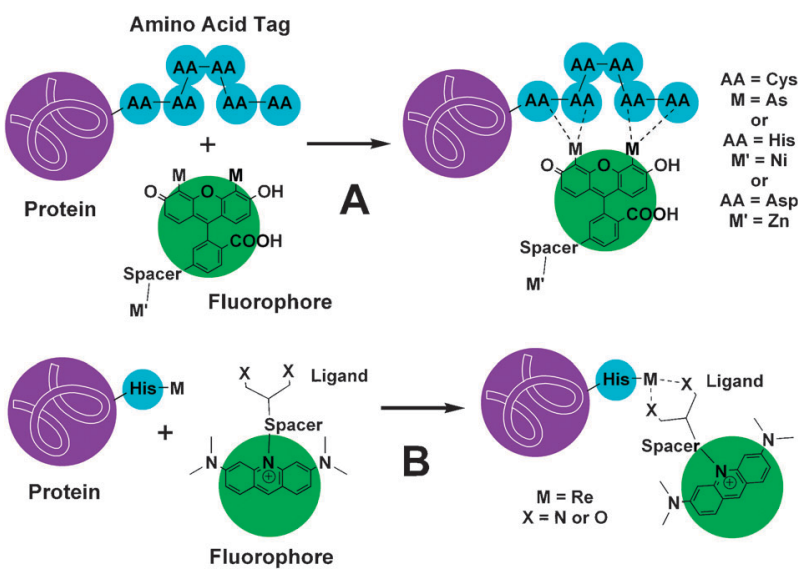

Scheme 1 (A) example of current strategies for the affinity labeling of proteins based on metal-chelation. (B) Our post-protein binding metal-mediated coupling approach.

(c) the oligo-aspartate/zinc-complex system ${ }^{18-22}$ and (d) the lanthanide-binding tag system..$^{23-27}$

With the exception of the lanthanide system, all affinity labelling based on metal-chelation rely on the synthesis of fluorescent metal complexes and their subsequent reaction with the amino acid tag. To the best of our knowledge, there is no example in the literature of an approach which exploits the reactivity of an organic dye with an exogenous metal fragment previously hybridized on the protein of interest (see Scheme 1B). Such a strategy requires the formation of a robust protein-metal bond capable of withstanding the subsequent reaction with the fluorophore. Furthermore, the resulting fluorescent adduct should be stable under physiological conditions and should not alter significantly the protein function. 
Several studies have now made available structural information of the interactions of transition metal complexes with different proteins. ${ }^{28-32}$ However, very little is known about the reactivity of the hybridized species in terms of post-protein binding modifications which may occur to the metal fragment. Understanding the chemistry of protein-bound metal species might offer an elegant alternative to the current affinity labelling based on metal-chelation techniques (Scheme 1A) by first engineering and artificial metallo-protein and then taking advantage of the metal affinity for ligands bearing fluorescent tags. This approach, as shown in Scheme $1 \mathrm{~B}$, is reminiscent of the so-called inverted $[2+1]$ approach, ${ }^{33}$ a method routinely employed in radiopharmaceutical chemistry for the coupling of radioactive isotopes (e.g. Tc $\left.{ }^{99 \mathrm{~m}}\right)$ with biomolecules. ${ }^{34}$

As a model for our study, we chose the HEW lysozyme (Lys) and the $f a c-\left[\operatorname{Re}(\mathrm{CO})_{3}\left(\mathrm{H}_{2} \mathrm{O}\right)_{3}\right]^{+}$complex (1). The interaction of $\mathbf{1}$ with Lys has been the subject of recent work of Ziegler and co-workers. ${ }^{35,36}$ The author showed that exposure of Lys to 3-5 equivalents of $\mathbf{1}$ is sufficient to obtain a stable adduct and analysis of the x-ray structure of the metalloenzyme indicated a Re ion occupancy of $c a .60 \%{ }^{36}$ Intrigued by this report we wondered how the nature of the chiral protein environment might influence the chemistry of $\mathbf{1}$. In particular, within the contest just described, it was of interest to us to probe the reactivity of the protein-bound metal ion with ligands bearing a fluorescent tag.

To this end we selected a bifunctional chelator coupled with an acridine organe (AO) fluorophore recently described. ${ }^{33,37}$ We reasoned that if the chemistry of $\mathbf{1}$ is not significantly altered by the coordination of the metal ion on the protein surface, the bifunctional fluorophore chelator might result in the formation of a fluorescent complex ${ }^{33,37}$ and thus provide the tag for the metallo-protein adduct.

\section{Experimental}

\section{Materials and methods}

Chemicals and solvents were purchased from standard sources. Hen lysozyme was obtained from Sigma-Aldrich and was used as received. $\left(\mathrm{NEt}_{4}\right)_{2}\left[\mathrm{ReBr}_{3}(\mathrm{CO})_{3}\right](\mathbf{1})$ and the fluorophore 10-(4-(2,4-di-carboxy-1 $H$-imidazol-1-yl)butyl)3,6-bis(dimethylamino)acridinium (AO) were synthesized as previously described. ${ }^{33,37}$ IR spectra were recorded as pellets (KBr) using a Perkin Elmer Spectrum BX FT-IR spectrometer. UV/Vis spectra were taken on a Perkin Elmer Cary 50 spectrometer with a Peltier thermostat. Mass spectra were recorded in the positive mode on an Esquire HCT from Bruker (Bremen, Germany) with electrospray ionization (ESI). Highresolution electrospray mass spectra were recorded on a Bruker maXis QTOF-MS instrument (Bruker Daltonics $\mathrm{GmbH}$, Bremen, Germany). The samples were dissolved in a $1: 1$ mixture of $\mathrm{MeOH}$ and $0.1 \%$ formic acid and analyzed via continuous flow injection at $30 \mu \mathrm{min}^{-1}$. The mass spectrometer was operated in positive ion mode with a capillary voltage of $4 \mathrm{kV}$, an endplate offset of $-500 \mathrm{~V}$, a nebulizer pressure of $5.8 \mathrm{psig}$, and a drying gas flow rate of $41 \mathrm{~min}^{-1}$ at $180{ }^{\circ} \mathrm{C}$. The instrument was calibrated with a sodium formate solution $(500 \mu \mathrm{l}$ $\mathrm{H}_{2} \mathrm{O}: 500 \mu \mathrm{l}$ iPrOH:20 $\mu \mathrm{l} \mathrm{HCOOH}: 20 \mu \mathrm{l} 0.1 \mathrm{M} \mathrm{NaOH}$ aq).
The resolution was optimized at 30000 FWHM in the active focus mode. The accuracy was better than $2 \mathrm{ppm}$ in a mass range between $m / z 118$ and 1900. All solvent used were purchased in best LC-MS qualities. Dynamic light scattering (DLS) measurements were recorded on a DynaPro Titan TC device (Wyatt Technology) in water $\left(25^{\circ} \mathrm{C}, \mathrm{pH} 6.21\right)$ at a protein concentration of $1 \mathrm{mg} \mathrm{ml}{ }^{-1}$. The instrument was calibrated with a solution of commercially available lysozyme (100 s accumulation as specified by the manufacturer). Measurements for each sample were repeated four times. Data showing a polydispersity higher than $15 \%$ were discarded and repeated. Results reported in the ESI $\dagger$ are given as an average of four measurements.

\section{Analytical HPLC method}

Instrument: MERCK HITACHI LaChrom with a D-7000 interface coupled with a Diode Array detector L-7455 and a pump L-7100 system. Column: Macherey-Nagel, EC250/3 Nucleosil 100-5 C18. Flow rate: $0.5 \mathrm{ml} \mathrm{min}^{-1}$ for analysis; $5 \mathrm{~m}^{-1} \mathrm{~min}^{-1}$ preparative. Absorbance was monitored at 270 and $490 \mathrm{~nm}$. Solutions: A: $0.1 \%$ trifluoroacetic acid in water; B: methanol. Chromatographic method: (1) purification of Lys1: 0-5 min: isocratic flow of 75\% A-25\% B; 5-8 min: linear gradient to $31 \% \mathrm{~B} ; 8-9 \mathrm{~min}$ : linear gradient to $50 \% \mathrm{~B}$; 9-10 min: linear gradient to $25 \% \mathrm{~B} ; 10-11 \mathrm{~min}$ : linear gradient to $100 \% \mathrm{~B}$; 11-17 min: isocratic flow of $100 \% \mathrm{~B} ; 17-18 \mathrm{~min}$ : linear gradient to $75 \% \mathrm{~A}-25 \% \mathrm{~B} ; 18-20 \mathrm{~min}$ : isocratic flow. (2) purification of Lys2: 0-5 min: isocratic flow of 75\% A-25\% B; 5-10 min: linear gradient to $34 \% \mathrm{~B} ; 10-10.1 \mathrm{~min}: 50 \% \mathrm{~B} ; 10.1-12.5 \mathrm{~min}$ : isocratic flow of $50 \% \mathrm{~B} ; 12.4-12.5 \mathrm{~min}: 60 \% \mathrm{~B} ; 12.5-15 \mathrm{~min}$ : isocratic flow of $60 \% \mathrm{~B} ; 15-15.1 \mathrm{~min}: 75 \% \mathrm{~B} ; 15.1-20 \mathrm{~min}$ : isocratic flow of $75 \% \mathrm{~B} ; 20-20.1 \mathrm{~min}: 100 \% \mathrm{~B} ; 20.1-28 \mathrm{~min}$ : isocratic flow of $100 \% \mathrm{~B} ; 28.1-30 \mathrm{~min}$ : linear gradient to $75 \% \mathrm{~A}-25 \% \mathrm{~B}$.

\section{Synthesis of Lys1}

To a solution of $50 \mathrm{mg}$ of Lys dissolved in $3 \mathrm{ml}$ of distilled water, $55 \mathrm{mg}$ of $\mathbf{1}$ ( $c a .20$ eq.) were added. The reaction mixture was gently stirred at room temperature for 7 days. The content of the mixture was monitored by HPLC-MS and the reaction stopped when no further evidence of free Lys could be detected. Note: in some cases longer reaction time or further addition of $\mathbf{1}$ is required to reach complete metallation of Lys. The mixture was then purified in portions by HPLC and the purity of each batch confirmed by HPLC-MS. During the chromatographic separation samples of Lys1 were obtained in a pure methanol fraction. In order to avoid possible denaturation of the enzyme, these fractions were collected in a flask containing distilled water, maintaining the $\varphi \mathrm{MeOH}$ fraction below enzymatic denaturation conditions $(\varphi \mathrm{MeOH}=0.3)$. Methanol was then gently removed on a rotatory evaporator, the aqueous solution frozen and then lyophilized. Compound Lys1 was thus obtained as a white light powder. Yield: $41-46 \mathrm{mg}, 80-90 \%$. HPLC analysis showed a single peak with a retention time of $14.52 \mathrm{~min}$. DLS control measurements were run on the final isolated samples in order to check for possible protein aggregation. Analytical data for Lys1: ESI-MS analysis (positive mode) gave peaks at $m / z=1215.3(+12$ ion), 1327.1 ( +11 ion), 1458.5 ( +10 ion), 1620.4 ( +9 ion), 1823.0 ( +8 ion). IR (solid state, $\left.\mathrm{KBr}, \mathrm{cm}^{-1}\right): \nu \mathrm{C} \equiv \mathrm{O} 2025,1904$. 


\section{Synthesis of Lys2}

To a solution of $5 \mathrm{mg}$ of Lys1 dissolved in $0.75 \mathrm{ml}$ of distilled water, $0.35 \mathrm{ml}$ of a saturated solution of $\mathbf{A O}$ in $\mathrm{MeOH}$ were added. The reaction mixture was gently shaken at $37{ }^{\circ} \mathrm{C}$ for 24 hours and then stopped. HPLC analysis of the reaction mixture revealed partial demetallation of Lys1. The mixture was the filtered from excess AO, lyophilized, redissolved in pure water, filtered and lyophilized again. The light orange powder was then purified in portions by HPLC and the purity of each batch confirmed by HPLC and MS. An identical procedure to the purification of Lys1 was used. Lys2 was thus obtained an orange light powder. Yield: $1 \mathrm{mg}, 19 \%$. DLS control measurements were run on the final isolated samples in order to check for possible protein aggregation. HPLC analysis showed a single peak with a retention time of $26.45 \mathrm{~min}$. Analytical data for Lys2: ESI-MS analysis (positive mode) gave peaks at $m / z=1255.1$ ( +12 ion), 1369.1 ( +11 ion $), 1505.9$ ( +10 ion), 1673.1 ( +9 ion), 1882.0 ( +8 ion). IR (solid state, $\left.\mathrm{KBr}, \mathrm{cm}^{-1}\right): \nu \mathrm{C} \equiv \mathrm{O} 2029,1916-1897$.

\section{Determination of enzymatic activity by lysis of Micrococcus lysodeikticus}

An aliquot of a stock solution Lys, Lys1, or Lys2 $(0.5 \mathrm{mg}$ in $0.5 \mathrm{ml}$, prepared in a $0.1 \mathrm{M}$ phosphate buffer solution, $\mathrm{pH} 7.4$ ) was added to a suspension of Micrococcus lysodeikticus (M. lysodeikticus) cells ( $9 \mathrm{mg}$ in $30 \mathrm{ml}$, prepared in a $0.1 \mathrm{M}$ phosphate buffer solution, $\mathrm{pH} 7.4,25^{\circ} \mathrm{C}$ ), for a final concentration of $10 \mu \mathrm{g} \mathrm{ml}^{-1}$ of the enzyme. The change in turbidity of the solution was then monitored by UV-visible spectroscopy at a set wavelength of $450 \mathrm{~nm}$. Spectra were collected at $60 \mathrm{~s}$ intervals and the absorbance plotted against time.

\section{Confocal laser scanning microscopy (CLSM)}

M. lysodeikticus cells were suspended in a $0.1 \mathrm{M}$ phosphate buffer solution at $\mathrm{pH} 7.4$, to give a final concentration of $3 \mathrm{mg} \mathrm{ml}^{-1}$. Lys2, at final concentrations of 1 and $10 \mu \mathrm{g} \mathrm{ml}^{-1}$, was added and digestion was allowed to proceed for $10 \mathrm{~min}$ at $37{ }^{\circ} \mathrm{C}$. The reaction was then stopped by placing the vessels in an ice bath. After Lys 2 treatment, the cells were fixed on glass slides by dehydration and analyzed by CLSM. The confocal laser scanning microscope setup consisted of an Olympus BX 60 microscope equipped with a FluoView detector and laser operating at $488 \mathrm{~nm}$.

\section{Computational details}

Geometry optimizations of Lys1 and Lys2 complexes were performed with the Gaussian03 program package with the 2-layer ONIOM QM:MM method. ${ }^{38,39}$ The QM region, which consists of $\left[\mathrm{Re}(\mathrm{CO})_{3}\left(\mathrm{H}_{2} \mathrm{O}\right)_{2}\right]$ in Lys1 and $\left[\mathrm{Re}(\mathrm{CO})_{3}(\mathrm{AO})_{2}\right]$ in Lys2 augmented with the metal-coordinated imidazole ring in both cases, was treated at the B3LYP level ${ }^{40}$ with the LANL2DZ ${ }^{41-44}$ basis set while the UFF force field ${ }^{41}$ was used for the rest of the lysozyme (MM region). The $\mathrm{QM}$ region and some terminal amino acids in the vicinity of the rhenium fragment were allowed to move during the geometry optimizations; the remaining atoms were kept fixed to save CPU time.

\section{Results and discussion}

In order to probe the reactivity of the lysozyme-bound fac- $\left[\mathrm{Re}(\mathrm{CO})_{3}\left(\mathrm{H}_{2} \mathrm{O}\right)_{2}\right]^{+}$complex, we first directed our efforts towards developing a synthetic strategy that would allow the quantitative metallation of Lys. We found that complete metallation of the enzyme could be attained by reacting Lys with an excess of 1 ( $>20$ eq.) for 7 days at room temperature (see Scheme 2). Chromatographic purification of Lys1 allowed isolating the protein in $c a$. $80 \%$ yield with no apparent loss of the metal ion (typically on a $50 \mathrm{mg}$ scale). The metallated protein thus obtained could also be crystallized but we found no significant differences with the reported structure $^{36}$ with the exception that Re occupancy could be modelled to a value $>80 \%$.

Subsequent coupling of the 10-(4-(2,4-di-carboxy-1Himidazol-1-yl)butyl)-3,6-bis(dimethylamino)acridinium fluorophore (AO) to Lys1 was carried out in a mixture of water and methanol at $\varphi \mathrm{MeOH}$ fraction below enzymatic denaturation conditions $(\varphi \mathrm{MeOH}<0.4$, see Scheme 2$) .{ }^{45}$ Preliminary studies of interactions of Lys with $\mathbf{1}$ and of Lys1 with AO were always followed by HPLC and LC-MS analysis. For the formation of Lys1 the LC-MS proved most effective as our chromatographic assay did not allow distinguishing between Lys and Lys1 (see Fig. 1). LC-MS analysis, on the other hand, could provide a clear indication of the complete metallation of Lys (Fig. 2, vide infra). For the formation of Lys2, LC-MS never gave satisfactory results. Only after chromatographic purification and lyophilization of the adduct, direct MS injections showed a clear pattern of signals corresponding to Lys2 (Fig. 2, vide infra). The reaction leading to the formation of $\mathbf{L y s} \mathbf{2}$ induced

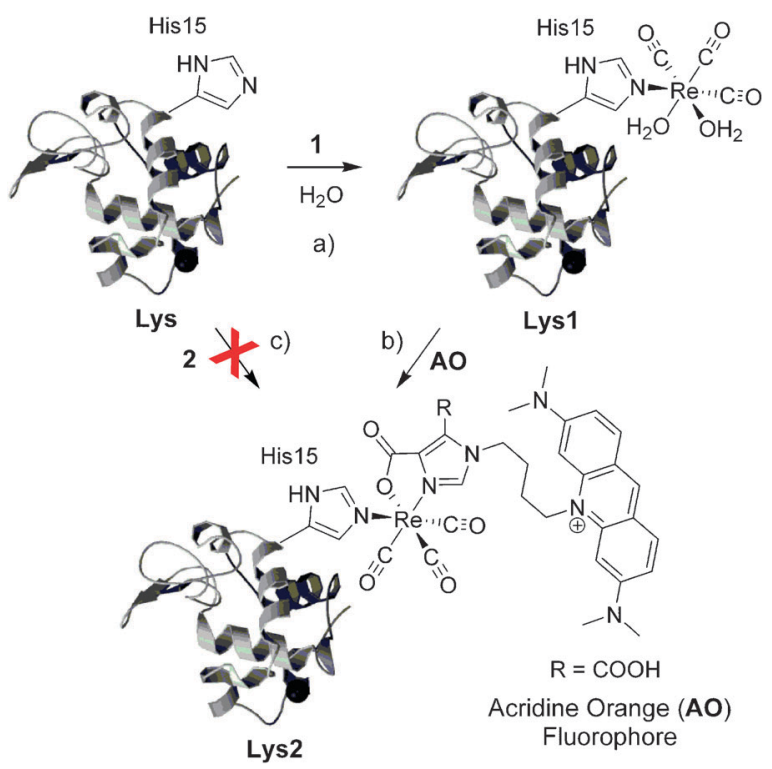

Scheme 2 Reaction sequence leading to the formation of Lys1 and Lys2. Complete metallation of HEW lysozyme (Lys) is attained by allowing the protein to react with an excess of $f a c$ - $\left[\operatorname{Re}(\mathrm{CO})_{3}\left(\mathrm{H}_{2} \mathrm{O}\right)_{3}\right]^{+}$ (a). In Lys1 the metal ion has two available coordination sites which may be further derivatized with 10-(4-(2,4-di-carboxy-1H-imidazol-1-yl)butyl)-3,6-bis(dimethylamino)acridinium (AO) (b). Lys2 could not be generated by reacting the isolated $f a c-\left[\operatorname{Re}(\mathrm{CO})_{3}(\mathbf{A O})\left(\mathrm{H}_{2} \mathrm{O}\right)\right]$ complex (2) with Lys (c). 


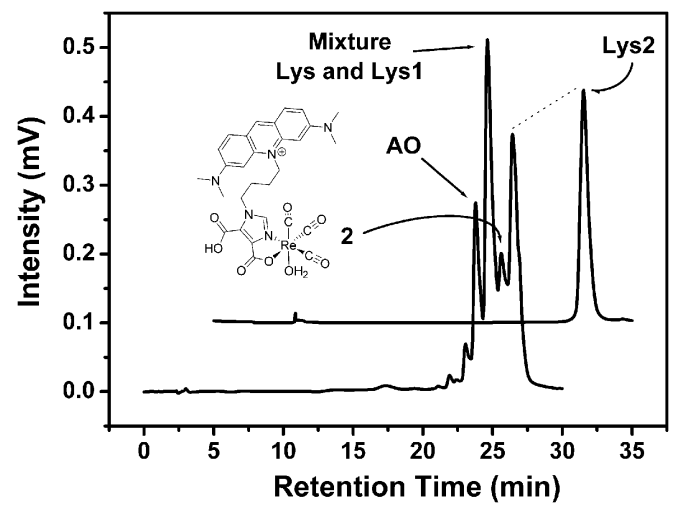

Fig. 1 HPLC chromatograms of the mixture obtained from the reaction of Lys1 with AO (bottom spectrum) and the purified Lys2 sample. Peaks were assigned via MS analysis on the isolated samples. The top chromatogram is offset by 5 min for clarity.

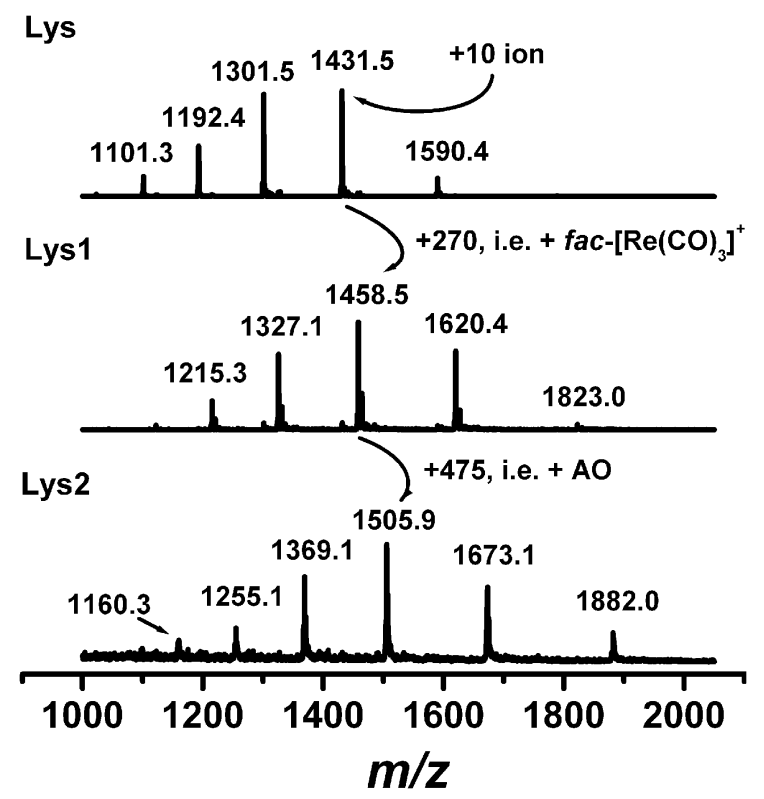

Fig. 2 Electrospray ionization (ESI, positive mode) mass spectra of (from top to bottom) Lys, Lys1 and Lys2. Spectra of Lys1 and Lys2 were recorded on powder samples collected after chromatographic purification.

partial demetallation of Lys1 and the corresponding free $\mathrm{fac}_{\text {- }}$ $\left[\operatorname{Re}(\mathrm{CO})_{3}(\mathbf{A O})\left(\mathrm{H}_{2} \mathrm{O}\right)\right]$ complex (2) was also detected in solution via HPLC and electrospray ionization (ESI, positive mode) analysis (Fig. 1).

Under our experimental conditions, MS analysis of the Lysand Lys1-derived species showed a distinct pattern of signals (typically 5 , in some cases up to 6 ) corresponding to the +9 to the +13 ions (or +8 to +13 ions) of the proteins (Fig. 2). Changes in the position of the signal patterns offered an immediate indication of the type of interactions which resulted from the reactions.

Unmodified Lys has a molecular weight of $14.31 \mathrm{kDa}$. In a $1: 1$ methanol : $0.1 \%$ formic acid water solution, ESI (positive mode) mass spectra of commercially available samples of Lys showed signals ranging from $1101.3 \mathrm{~m} / z$ ( +13 ion) to $1590.4 \mathrm{~m} / \mathrm{z}$ ( +9 ion) with the reference +10 ion centred at $1431.5 \mathrm{~m} / z$ (Fig. 2). Coordination of 1 to the His 15 residue of Lys caused an increase in mass of the enzyme of 270 mass units. Correspondingly, the +10 ion of Lys 1 was detected at $1458.5 \mathrm{~m} / \mathrm{z}$. The observed mass change relates exactly to the weight of the $f a c$ - $\left[\operatorname{Re}(\mathrm{CO})_{3}\right]^{+}$core (the water molecules completing the Re coordination sphere were never detected). Similarly coupling of AO to Lys1 shifted the +10 ion of Lys2 to $1505.9 \mathrm{~m} / \mathrm{z}$.

Crystallization of samples of Lys2 was attempted under a wide variety of conditions, but no diffracting crystals could be obtained. Soaking of Lys crystals with solutions of $\mathbf{2}$ (isolated during the HPLC purification of Lys2) was also unsuccessful in all cases. An excess of $\mathbf{2}$ was then reacted free Lys (5 mg Lys scale) in order to obtain significant amounts of Lys2 to employ in the crystallization attempts. Strikingly no reaction was observed over a period several days. Reactions repeated in a water/DMSO mixture at a $\varphi_{\text {DMSO }}$ fraction below enzymatic denaturation ${ }^{45}$ conditions $\left(37^{\circ} \mathrm{C}, 5\right.$ days $)$ showed no evidence of 2 binding to the protein.

We attribute the lack of crystallization of Lys 2 to partial loss of proper folding of the adduct. In order to obtain clean samples, Lys 2 was subjected to several consecutive chromatographic purifications which might have affected the tertiary structure of the protein. Near-UV circular dichroism (CD) measurements confirmed this assumption (ESI $\dagger$ ). Indeed, while Lys and Lys1 show similar CD spectra with a positive maximum at $c a .284 \mathrm{~nm}$, Lys 2 shows a broadened spectrum with decreased intensity in the same region $(\mathrm{ESI} \dagger)$. Furthermore, experiments aimed at confirming enzymatic activity of Lys2 via lysis of Micrococcus lysodeikticus (vide infra) showed a reduced rate when compared to Lys and Lys1. However, in order to obtain insights into the structure of Lys2, calculations at the density functional (QM) and molecular mechanics (MM) level of theory were performed. A model of the calculated adduct is shown in Fig. 3.

The infra-red (IR) spectra of the natural lysozyme and the two rhenium-modified adducts were investigated to confirm the presence of the bound $f a c-\left[\operatorname{Re}(\mathrm{CO})_{3}\right]^{+}$core in samples of

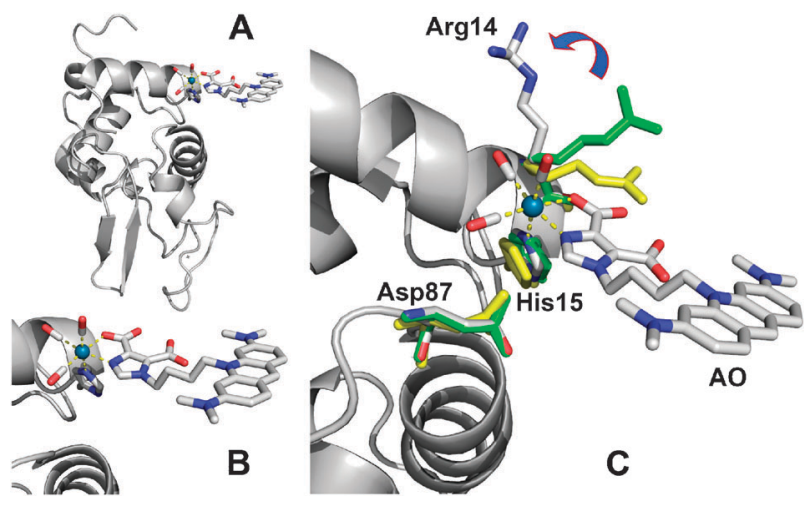

Fig. 3 (A) Calculated overall structure of a $Q M / M M$ model of Lys2. (B) Detailed view of the Re binding site. (C) Comparison of the position of the amino acid residues in the Re binding site in the $\mathrm{x}$-ray structure of Lys1 (yellow, PDB entry $3 \mathrm{KAM}$ ), ${ }^{36}$ the QM/MM structure of Lys1 (green) and the QM/MM structure of Lys2 (grey/ element coded). The Arg14 amino acid suffers the greatest change consistent with the rearrangement of the residue required to lift the steric hindrance at the binding site. The pictures were prepared using the Pymol software. ${ }^{46}$ 


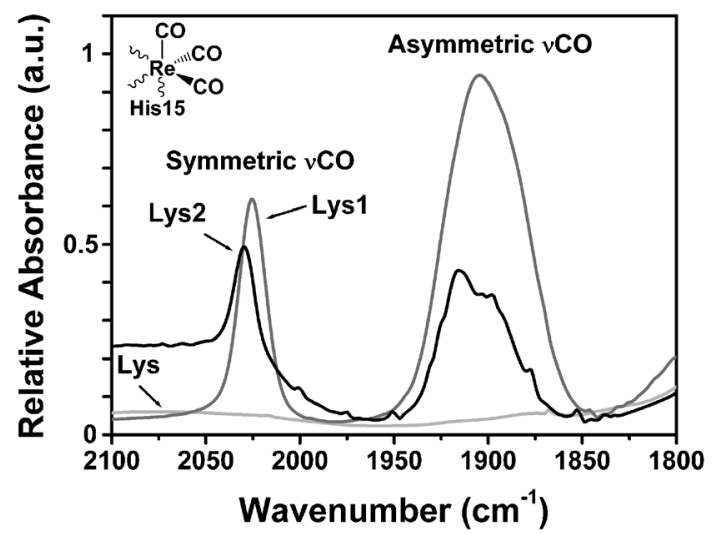

Fig. 4 Selected region $\left(2100-1800 \mathrm{~cm}^{-1}\right)$ of the IR spectra (recorded as solid $\mathrm{KBr}$ pellets) of Lys (light grey), Lys1 (grey) and Lys2 (black). Note the two strong $\nu \mathrm{CO}$ absorptions in the samples of Lys1 and Lys2 confirming the presence of the bound $f a c-\left[\operatorname{Re}(\mathrm{CO})_{3}\right]^{+}$core.

Lys1 and Lys2 (Fig. 4). In the IR region between 1800 and $2050 \mathrm{~cm}^{-1}$, low spin $\mathrm{d}^{6}$ rhenium tricarbonyl complexes show distinctive vibrational frequencies attributed to the symmetric $\left(a_{1}\right)$ and the asymmetric $(e)$ stretching modes of the bound CO ligands. While, as expected, Lys is transparent in this region, both Lys1 and Lys2 show $\nu$ CO bands characteristic of the $f a c-\left[\operatorname{Re}(\mathrm{CO})_{3}\right]^{+}$core, respectively, at 2025 and $2029 \mathrm{~cm}^{-1}$ ( $a_{1}$ mode) and at 1904 and $1916-1897 \mathrm{~cm}^{-1}$ (e mode, Fig. 4). The measured values of Lys1 differ from the ones previously reported by Ziegler and co-workers in two aspects. ${ }^{35,36}$ In our sample, the position of the symmetric stretching band ( $a_{1}$ mode) is hypsochromically shifted by $c a .10 \mathrm{~cm}^{-1}$ and no splitting is observed (Fig. 4). ${ }^{35,36}$ It should be mentioned, however, that previous IR measurements were determined on crystals of Lys1 and the splitting of the symmetric mode was attributed to the presence of multiple rotamers in the $\mathrm{x}$-ray structure of the metalloprotein. ${ }^{35,36} \mathrm{We}$ note that coordination of $\mathbf{A O}$ to Lys1 did not significantly affect the $\nu \mathrm{CO}$ frequencies of the $f a c-\left[\operatorname{Re}(\mathrm{CO})_{3}\right]^{+}$core in Lys2.

The UV-visible and the emission spectra of compounds 2 and Lys2 are shown in Fig. 5. Both species exhibit a pronounced AO-based absorption centred at $496 \mathrm{~nm}$ together with strong absorptions in the UV region between 250 and $325 \mathrm{~nm}$. The spectra differ mainly in the intensity of the latter and the presence in the spectrum of Lys 2 of a peak at $388 \mathrm{~nm}$. Absorptions in the UV region are ascribed to $\pi$ to $\pi^{*}$ transitions of aromatic residues and they are more intense in Lys2 given the presence of several amino acid bearing aromatic side chains (e.g. phe, tyr and trp). The peak at $388 \mathrm{~nm}$ was tentatively assigned to the coordination of $\mathbf{2}$ to the His 15 residue of the protein, however theoretical calculations are not in support of this assumption (results not shown). As expected $\mathbf{2}$ and Lys2 display strong fluorescence. Both species show a maximum emission at $520 \mathrm{~nm}$ when excited at $496 \mathrm{~nm}$. The position and the intensity of the fluorophore (AO) emission maximum do not appear to be influenced by the coordination of the metal complex onto the enzyme.

Prior to confocal laser scanning microscopy (CLSM) experiments, enzymatic activity of the natural lysozyme and the two rhenium-modified adducts was investigated according to a modification of the procedure described by Shugar. ${ }^{47}$ The assay

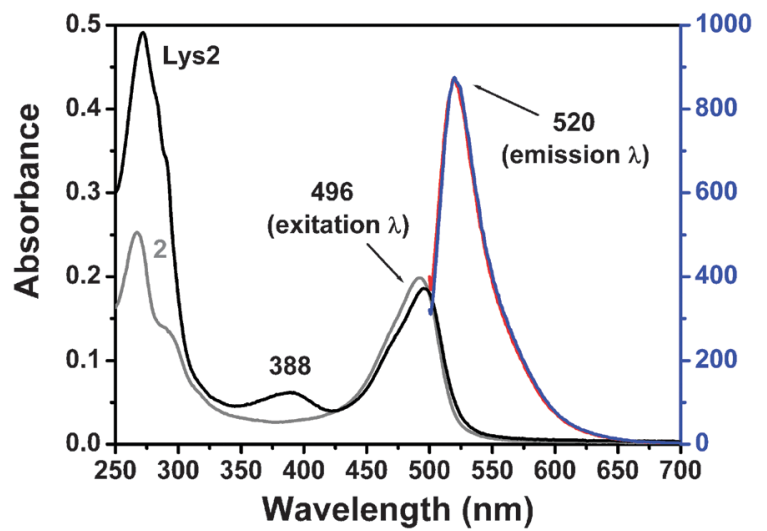

Fig. 5 UV-visible $(20 \mu \mathrm{M}$, referenced to the $y$-axis on the left $)$ and emission spectra ( $10 \mu \mathrm{M}$, referenced to the $y$-axis on the right) of $\mathbf{2}$ and Lys2.

entails measuring the rate at which lysozyme containing samples can clear up turbid suspensions of $M$. lysodeikticus cells. Briefly, the cell wall of $M$. lysodeikticus consists largely of a polymeric peptidoglycan in which $N$-acetylglucosamine (NAG) and $N$-acetylmuramic acid (NAM) are linked by glycosidic bonds to form polymeric chains. ${ }^{48}$ Lysozyme catalyzes the hydrolysis of the NAM $(1 \rightarrow 4)$ NAG bond causing disruption of the cells and dispersion of their contents. ${ }^{48}$ The turbidity that may be seen in suspensions of the bacterial cells is due largely to the light scattering that takes place at the interface between cells and medium, and at discontinuities within the cells. As the cells are destroyed and dispersed, clearing occurs.

Fig. 6 shows the effect on the lysis on a suspension of M. lysodeikticus cells by the action of Lys, Lys1 and Lys2. While Lys and Lys1 showed virtually identical rates ${ }^{49}$ of lysis $\left(19.33 \pm 0.23\right.$ and $19.15 \pm 0.19 \mu \mathrm{g}$ protein $\mathrm{s}^{-1} \mathrm{ml}^{-1}$ respectively), a $c a .35 \%$ reduction of the activity of Lys 2 was measured (i.e. rate of lysis of $\mathbf{L y s} \mathbf{2}=12.40 \pm 0.07 \mu \mathrm{g}$ protein $\mathrm{s}^{-1} \mathrm{ml}^{-1}$ ). As mentioned above, this discrepancy is attributed to partial loss of tertiary protein structure of Lys2 which resulted from its chromatographic purification.

Confocal laser scanning microscopy (CLSM) experiments were performed in order to verify the possibility of observing the action

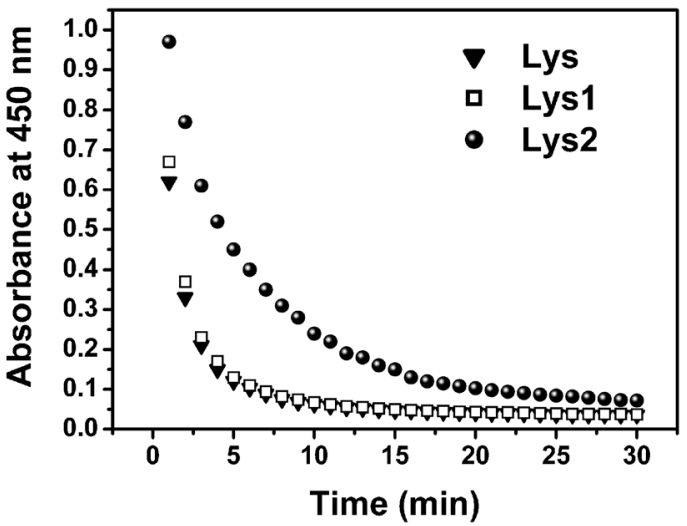

Fig. 6 Lysis of M. lysodeikticus by Lys, Lys1 and Lys2 (10 $\mu \mathrm{g}$ of enzyme $\mathrm{ml}^{-1}$, in $0.1 \mathrm{M}$ phosphate buffer $\mathrm{pH} 7.4,25^{\circ} \mathrm{C}$ ) monitored as a time function of the sample OD at $450 \mathrm{~nm}$. Spectra intervals are $1 \mathrm{~min}$. The estimated error of the measurements is $c a .1 \%$. 

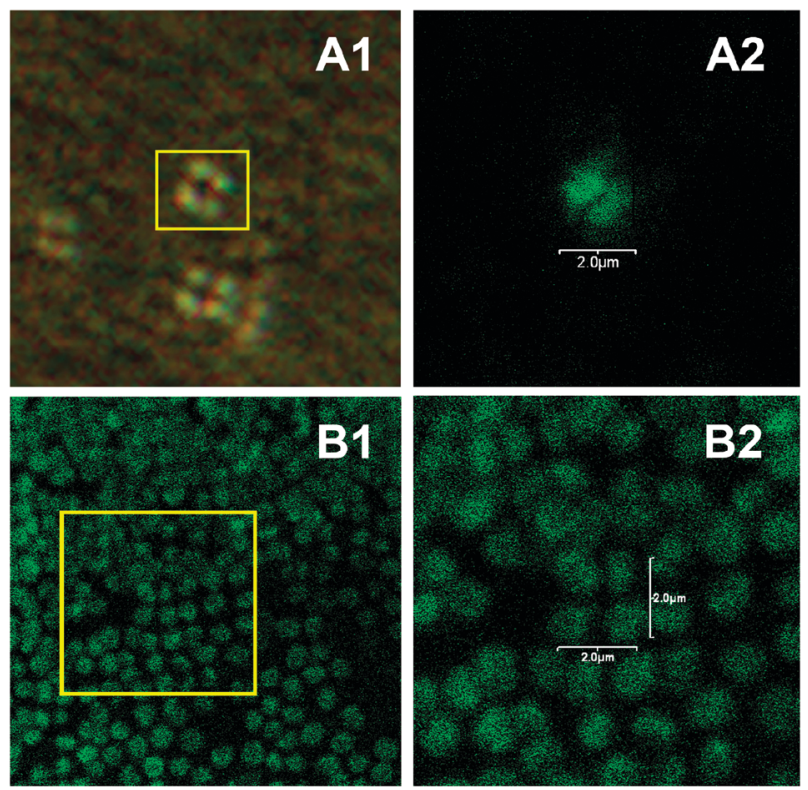

Fig. 7 Confocal laser scanning microscopy (CLSM) pictures of M. lysodeikticus bacteria incubated with 1 (A1 and A2) and $10 \mu \mathrm{g} \mathrm{ml}^{-1}$ (B1 and B2) of Lys2 for $10 \mathrm{~min}$ at $37^{\circ} \mathrm{C}$. A1: bright field image of isolated M. lysodeikticus tetrads. A2: fluorescent image of A1. B1: fluorescent image of a large colony of bacteria. B2: detail view of B1.

of fluorescent Lys2 on M. lysodeikticus cells. M. lysodeikticus is a gram-positive, spherical bacterium which forms tetrads, i.e. cocci that fail to separate after they divide, and remain in groups of four forming squares of $c a .4 \mu^{2}{ }^{50}$ This morphological feature can be clearly seen in Fig. 7(A1). Experiments were performed at two different concentrations of the enzyme, namely 1 (Fig. 7A1 and A2) and $10 \mu \mathrm{g} \mathrm{ml}^{-1}$ (Fig. 7B1 and B2).

Incubating the bacteria with Lys 2 for $10 \mathrm{~min}$ at $37{ }^{\circ} \mathrm{C}$ allowed visualizing the accumulation of the modified lysozyme on the cells. In all our experiments the interaction of Lys 2 on M. lysodeikticus cells produced a punctuated like accumulation of the protein around the bacteria. A similar heterogeneous distribution was also previously observed with other peptides labelled with similar fluorophores. ${ }^{33}$ It should be mentioned that in our experimental set-up it was not possible to conclusively determine the location of the fluorescent enzyme. There are several considerations which caution us from a detailed discussion on the subject.

First, the resolution of our microscope $(<1 \mu \mathrm{m})$ did not permit the observation of "ring-like" structures by varying the line of focus along the $z$-axis (i.e. by cutting through the cells). Such ring-like structures could be considered as proof for the accumulation of Lys $\mathbf{2}$ on the outer membrane of the bacteria. Instead, small variations of the line of focus resulted in the nearly complete disappearance of fluorescence. Second, incubating Lys2 in water at $37{ }^{\circ} \mathrm{C}$ for $30 \mathrm{~min}$ showed no change in the UV-visible spectrum of the adduct. This suggests that given the incubation time of $10 \mathrm{~min}$ prior to CLSM experiments, fluorescence may be assigned to Lys2 and not to $\mathbf{2}$ or AO. However, as cells are destroyed and their content released there could be other reactions leading to the demetallation of Lys2. Third, as the thick peptidoglycan layer is digested by Lys2, large opening is formed on the bacteria, allowing the diffusion of the enzyme within the cytoplasm. Nevertheless, CLSM clearly showed accumulation of Lys2 on M. lysodeikticus cells and allowed the visualization of the typical tetrad morphology of the bacteria (see Fig. 7).

\section{Conclusions}

By using HEW lysozyme (Lys) as a simple model protein, we have described an alternative strategy for labelling polypeptides with a fluorescent tag via coordination reactions of an acridine orange-based fluorophore (AO) with a non-native metal fragment hybridized on the enzyme (Lys1). A synthetic methodology for the quantitative metallation of the enzyme was described. It was shown that the exogenous metal complex could be exploited for the coupling of the fluorescent probe. Direct reaction of the natural protein with the corresponding metal species (2) did not yield the adduct of interest (Lys2). The high chemical affinity of the $f a c-\left[\operatorname{Re}(\mathrm{CO})_{3}\right]^{+}$core for imidazole type ligands (and thus histidine) could make the strategy herein described generally feasible for other proteins with available histidines accessible for coordination. Current efforts in our lab are directed at elucidating the chemistry of the $f a c-\left[\operatorname{Re}(\mathrm{CO})_{3}\right]^{+}$core and other metal fragments on different natural polypeptides.

\section{Acknowledgements}

The Swiss National Science Foundation (Ambizione PZ00P2_121989) and the Forschungskredit of the University of Zürich (credit number 57010204) are acknowledged for financial support. We thank Nando Gartmann (University of Zürich) for his assistance during confocal laser scanning microscopy experiments.

\section{Notes and references}

1 J. Lippincott-Schwartz and G. H. Patterson, Science, 2003, 300, 87-91.

2 N. C. Shaner, P. A. Steinbach and R. Y. Tsien, Nat. Methods, 2005, 2, 905-909.

3 R. Y. Tsien, Annu. Rev. Biochem., 1998, 67, 509-544.

4 Y. W. Wu and R. S. Goody, J. Pept. Sci., 2010, 16, 514-523.

5 M. Andresen, R. Schmitz-Salue and S. Jakobs, Mol. Biol. Cell, 2004, 15, 5616-5622.

6 C. S. Lisenbee, S. K. Karnik and R. N. Trelease, Traffic, 2003, 4, 491-501.

7 B. Krishnan, A. Szymanska and L. M. Gierasch, Chem. Biol. Drug Des., 2007, 69, 31-40.

8 B. A. Griffin, S. R. Adams and R. Y. Tsien, Science, 1998, 281 269-272.

9 S. R. Adams, R. E. Campbell, L. A. Gross, B. R. Martin, G. K. Walkup, Y. Yao, J. Llopis and R. Y. Tsien, J. Am. Chem. Soc., 2002, 124, 6063-6076.

10 K. E. Poskanzer, K. W. Marek, S. T. Sweeney and G. W. Davis, Nature, 2003, 426, 559-563.

11 C. C. Spagnuolo, R. J. Vermeij and E. A. Jares-Erijman, J. Am. Chem. Soc., 2006, 128, 12040-12041.

12 H. S. Cao, Y. J. Xiong, T. Wang, B. W. Chen, T. C. Squier and M. U. Mayer, J. Am. Chem. Soc., 2007, 129, 8672-8673.

13 A. K. Bhunia and S. C. Miller, ChemBioChem, 2007, 8, 1642-1645.

14 A. N. Kapanidis, Y. W. Ebright and R. H. Ebright, J. Am. Chem. Soc., 2001, 123, 12123-12125.

15 C. R. Goldsmith, J. Jaworski, M. Sheng and S. J. Lippard, J. Am. Chem. Soc., 2006, 128, 418-419.

16 S. Lata, A. Reichel, R. Brock, R. Tampe and J. Piehler, J. Am. Chem. Soc., 2005, 127, 10205-10215.

17 E. G. Guignet, R. Hovius and H. Vogel, Nat. Biotechnol., 2004, 22, $440-444$. 
18 K. Honda, E. Nakata, A. Ojida and I. Hamachi, Chem. Commun., 2006, 4024-4026.

19 A. Ojida, K. Honda, D. Shinmi, S. Kiyonaka, Y. Mori and I. Hamachi, J. Am. Chem. Soc., 2006, 128, 10452-10459.

20 K. Honda, S. H. Fujishima, A. Ojida and I. Hamachi, ChemBioChem, 2007, 8, 1370-1372.

21 H. Nonaka, S. Tsukiji, A. Ojida and I. Hamachi, J. Am. Chem. Soc., 2007, 129, 15777-15779.

22 H. Nonaka, S. Fujishima, S. Uchinomiya, A. Ojida and I. Hamachi, J. Am. Chem. Soc., 2010, 132, 9301-9309.

23 K. J. Franz, M. Nitz and B. Imperiali, ChemBioChem, 2003, 4, 265-271.

24 K. J. Franz, M. Nitz, E. Lukovic and B. Imperiali, J. Inorg. Biochem., 2003, 96, 131-131.

25 M. Nitz, K. J. Franz, R. L. Maglathlin and B. Imperiali, ChemBioChem, 2003, 4, 272-276.

26 M. Nitz, M. Sherawat, K. J. Franz, E. Peisach, K. N. Allen and B. Imperiali, Angew. Chem., Int. Ed., 2004, 43, 3682-3685.

27 B. R. Sculimbrene and B. Imperiali, J. Am. Chem. Soc., 2006, 128, 7346-7352.

28 V. Calderone, A. Casini, S. Mangani, L. Messori and P. L. Orioli, Angew. Chem., Int. Ed., 2006, 45, 1267-1269.

29 A. Casini, G. Mastrobuoni, C. Temperini, C. Gabbiani, S. Francese, G. Moneti, C. T. Supuran, A. Scozzafava and L. Messori, Chem. Commun., 2007, 156-158.

30 A. Casini, C. Temperini, C. Gabbiani, C. T. Supuran and L. Messori, ChemMedChem, 2010, 5, 1989-1994.

31 I. W. McNae, K. Fishburne, A. Habtemariam, T. M. Hunter, M. Melchart, F. Y. Wang, M. D. Walkinshaw and P. J. Sadler, Chem. Commun., 2004, 1786-1787.

32 M. Razavet, V. Artero, C. Cavazza, Y. Oudart, C. Lebrun, J. C. Fontecilla-Camps and M. Fontecave, Chem. Commun., 2007, 2805-2807.
33 K. Zelenka, L. Borsig and R. Alberto, Org. Biomol. Chem., 2011, 9 , 1071-1078.

34 IAEA, Labelling of Small Biomolecules Using Novel Technetium-99m Cores, Technical Reports Series No. 459, International Atomic Energy Agency, Vienna, 2007.

35 S. L. Binkley, T. C. Leeper, R. S. Rowlett, R. S. Herrick and C. J. Ziegler, Metallomics, 2011, 3, 909-916.

36 S. L. Binkley, C. J. Ziegler, R. S. Herrick and R. S. Rowlett, Chem. Commun., 2010, 46, 1203-1205.

37 K. Zelenka, L. Borsig and R. Alberto, Bioconjugate Chem., 2011, 22, 958-967.

38 A. D. Becke, J. Chem. Phys., 1993, 98, 5648-5652.

39 T. H. Dunning Jr. and P. J. Hay, Modern Theoretical Chemistry, ed. H. F. Schaefer III, Plenum, New York, vol. 3, 1976.

40 P. J. Hay and W. R. Wadt, J. Chem. Phys., 1985, 82, 270-283.

41 P. J. Hay and W. R. Wadt, J. Chem. Phys., 1985, 82, 299-310.

42 W. R. Wadt and P. J. Hay, J. Chem. Phys., 1985, 82, 284-298.

43 S. Dapprich, I. Komaromi, K. S. Byun, K. Morokuma and M. J. Frisch, J. Mol. Struct.: THEOCHEM, 1999, 461, 1-21.

44 T. Vreven, K. S. Byun, I. Komaromi, S. Dapprich, J. A. Montgomery, K. Morokuma and M. J. Frisch, J. Chem. Theory Comput., 2006, 2, 815-826.

45 I. K. Voets, W. A. Cruz, C. Moitzi, P. Lindner, E. P. G. Areas and P. Schurtenberger, J. Phys. Chem. B, 2010, 114, 11875-11883.

46 W. T. DeLano, The PyMOL Molecular Graphics System, Delano Scientific, San Carlos, CA, USA, 2002.

47 D. Shugar, Biochim. Biophys. Acta, 1952, 8, 302-309.

48 P. Jolles, Angew. Chem., Int. Ed. Engl., 1969, 8, 227-294.

49 G. Gorin, S. F. Wang and L. Papapavl, Anal. Biochem., 1971, 39, 113-127.

50 M. Kocur, Z. Pacova and T. Martinec, Int. J. Syst. Bacteriol., 1972, 22, 218-223. 